\title{
ПРАКТИКО-ОРИЕНТИРОВАННОЕ ОБУЧЕНИЕ ПРИ ПОДГОТОВКЕ БУДУЩИХ УЧИТЕЛЕЙ ТЕХНОЛОГИИ В ВУЗЕ
}

\section{PRACTICE-ORIENTED TRAINING \\ IN THE PREPARATION OF FUTURE TECHNOLOGY TEACHERS \\ AT THE UNIVERSITY}

T. Dikova

E. Smirnova

Summary: For a long time, university education was primarily aimed at the process of knowledge transfer, industrial practices played a major role in this process, but now we can observe a reduction in this direction. Such a reduction has led to the fact that there is a shortage of graduates with a high level of practical knowledge and skills in the country, young specialists are joining the work process with great difficulty. In this situation, it is practice-oriented learning that is the salvation and gives the key to students obtaining skills, knowledge and skills that are significant in practice. The authors in the article briefly consider practiceoriented training in the preparation of future technology teachers at the university.

Keywords: practice-oriented training, highly qualified specialist, university graduate, technology teacher, professional competencies.
$\mathrm{K}$ ак отмечал Полисадов С.С., практико-ориентированное обучение - это в первую очередь сам процесс освоения учащимися образовательной программы, целью которого является формирование у студентов профессиональной компетенции. Рассматриваемые компетенции формируются в ходе выполнения учащимися реальных задач на практике. В основе такого вида обучения заложен симбиоз фундаментального общего образования и профессионально-прикладной подготовки [2, с.1].

Практико-ориентированное обучение является наиболее актуальным в наше время, основными причинами такой значимости являются:

- повышение эффективности обучения за счет повышения личностного статуса студента;

- повышение интереса студентов к практической и творческой составляющей обучения;

- присутствие обратной связи во взаимодействии «преподаватель - студент».

По аналогии с высказыванием Полисадова С.С. процесс подготовки будущих учителей технологии также должен проходить в рамках практико-ориентированного обучения, включающее в себя теорию, методическое
Дикова Татьяна Владимировна

доцент, ГОУ ВО МО «Государственный социально гуманитарный университет»

d.t.v@rambler.ru

Смирнова Елена Алексеевна

к.n.н., доцент, ГОУ ВО МО «Государственный социально гуманитарный университет» tehfa.1974@yandex.ru

Аннотация: Долгое время обучение в ВУзе было направлено в первую очередь на процесс передачи знаний, большую роль в этом процессе имели производственные практики, однако сейчас можно наблюдать сокращение данного направления. Такое сокращение привело к тому, что в стране стал ощущаться недостаток выпускников с высоким уровнем практических знаний и навыков, молодые специалисты с большим трудом вливаются в рабочий процесс. В этой ситуации именно практико-ориентированное обучение является спасением и дает залог получения студентами значимых на практике умений, знаний и навыков. Авторы в статье кратко рассматривают практико-ориентированное обучение при подготовке будущих учителей технологии в ВУЗе.

Ключевые слова: практико-ориентированное обучение, высококвалифицированный специалист, выпускник ВУЗа, учитель технологии, профессиональные компетенции.

сопровождение, практические навыки и самосовершенствование/самообучение. Основные цели обучения будущих учителей технологии расписаны в программе практико-ориентированного обучения. Выделим несколько самых главных:

- образование: самое важное - достижение результата (овладение студентами ЗУН, значимыми в будущей профессии учителя технологии);

- воспитание: самое важное - развитие чувства ответственности и профессионального долга;

- развитие: самое важное - развитие личности в целом, а в частности педагогических и профессиональных умений;

- рефлексия; одна из самых важных целей, никакая высокопрофессиональная подготовка студента не может существовать без рефлексии, в частности одной из ее задач является развитие способности анализировать педагогическую деятельность.

Основные подходы практико-ориентированного обучения при подготовке будущих учителей технологии в ВУЗе состоят из: 1. разных практик, в ходе которых студенты приобретают практические навыки, необходимые в будущей профессии «учитель технологии» (речь идет об учебной, производственной и преддипломной прак- 
тики); 2. Внедрение таких технологий, которые помогут формированию у студентов необходимых для их будущей профессии знаний, умений, навыков, а также важных для будущей профессии учитель технологии качеств личности; 3. Использование в ходе практико-ориентированного обучения инновационных и модульных форм деятельности; 4. Формирование у студентов осознанной мотивированности в приобретении профессиональных знаний, умений и навыков, создание условий для формирования этих ЗУН.

В отличие от традиционного обучения практико-ориентированное позволяет лучше решать такие задачи как [1]:

- формирование системного мышления будущего учителя технологии;

- формирование навыков объективного и конструктивного общения при решения групповых заданий;

- формирование эффективных навыков принятия решений как индивидуального, и группового характера;

- формирование целостного видения своей будущей профессии;

- формирование на высоком уровне интересов, мотивов, знаний и навыков в профессиональной сфере.

Несмотря на отлично зарекомендованный вид обучения, процесс внедрения практико-ориентированного обучения в ВУЗе имеет некоторые проблемы [3]:

- для проведения практико-ориентированного обучения необходимо постоянно повышать уровень самообразования и профессиональных компетенций преподавателя;

- установление долгосрочных связей с предприятиями, на базе которых возможно проведение производственных практик;

- необходимо практиковать внедрение творческих проектов для студентов 1-2 курсов, полученные выводы по которым можно было бы использовать для написания квалификационных работ;

- переобучение преподавателей, их перепрофилирование, позволяющее отойти от традиционной формы подачи знаний к практико-ориентированному обучению, к обучению студентов посредством приобретения практического опыта;
- необходимо регулярно осуществлять поиск талантливых студентов ВУЗов с целью приобщения их к научным исследованиям, грантам, а также осуществлять необходимое для этого стимулирование;

- необходима разработка системы стимулирования и повышения мотивированности студентов;

- увеличение числа исследовательских и проектных работ студентами.

По итогу нашей работы выделим, на наш взгляд, основные черты практико-ориентированного обучения будущих учителей технологии:

- инновационные формы занятости помогают формировать практико-обоснованные профессиональные компетенции и научно-практический опыт будущей деятельности студентов;

- практические занятия в стенах ВУЗа и на производственных предприятиях направлены на формирование профессиональных компетенций по профилю «учитель технологии»;

- данный вид обучения помогает студентам формировать практические навыки, умения и знания, необходимые для будущей профессии, а также важные для профессии «учитель технологии» качества личности;

- правильно созданная образовательная среда для студентов формирует у них осознанную мотивированность в получении профессиональных ЗУН.

Главная ценность практико-ориентированного обучения будущих учителей технологии, на наш взгляд, состоит в том, что в процессе нее студенты получают ценный практический опыт своей будущей профессии, помогает повысить и поддерживать профессиональные компетенции на достойном уровне. Уменьшение репродуктивной деятельности, а равно как и увеличение научной, исследовательской и практической составляющей обучения способствует качественной подготовки будущих специалистов, студенты, прошедшие практико-ориентированное обучение с первых дней своей профессиональной деятельности в школах и других учебных заведениях в состоянии показать свой высокий уровень профессионализма, необходимых знаний, умений, навыков и что немаловажно необходимых для профессии «учитель технологии» качеств личности.

\section{ЛИТЕРАТУРА}

1. Вербицкий, А.А. Активное обучение в высшей школе: контекстный подход [Текст]: метод, пособие / А.А. Вербицкий. - М.: Высш. шк., 1991.-207 с.

2. Полисадов С.С. Практико-ориентированное обучение в ВУЗе. [Электронный ресурс]. - Режим доступа: https://portal.tpu.ru/f_dite/conf/2014/2/ c2_Polisadov.pdf\#: :text=Практико-ориентированное\%20обучение\%20-\%20это\%20процесс,0бщего\%200бразования\%20и\%20профессионально-прикладной\%20подготовки. 
3. Сластенин В.А. Личностно ориентированные технологии профессионально-педагогического образования [Текст] /В.А. Сластенин//Сибирский педагогический журнал. - 2008. -№ 1. - С. 49-75.

(с Дикова Татьяна Владимировна (d.t.v@rambler.ru), Смирнова Елена Алексеевна (tehfa.1974@yandex.ru).

Журнал «Современная наука: актуальные проблемы теории и практики»
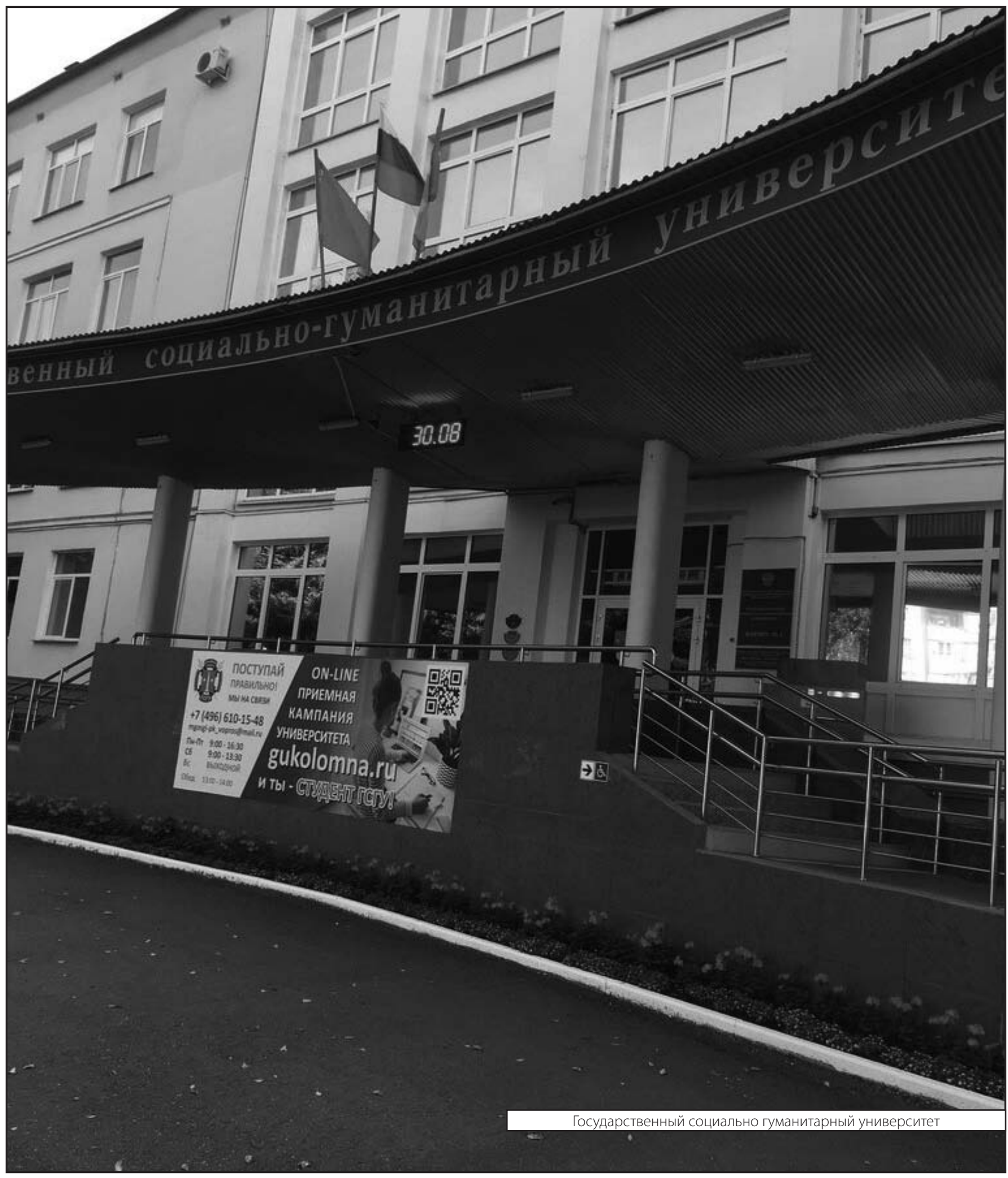